\title{
IMPLEMENTASI SUPERVISI AKADEMIK DALAM PENINGKATAN PROFESIONAL GURU TAMAN KANAK-KANAK DI TK PKK 1 YOSOMULYO METRO
}

\author{
Desi Srihayati ${ }^{1}$, M. Ihsan Dacholfany ${ }^{2 *}$, Sudirman AM. ${ }^{3}$ \\ ${ }^{1,2,3}$ Universitas Muhammadiyah Metro \\ E-mail: desisrihayati84@gmail.com ${ }^{1}$ ) \\ muhammadihsandacholfany@gmail.com ${ }^{2 *}$ \\ sudirman.am57@gmail.com ${ }^{3}$
}

\begin{abstract}
Abstrak
Profesional guru merupakan faktor penting dalam dunia pendidikan. Guru sebagai tenaga pendidikan mempunyai fungsi dan peran dalam kedudukan yang strategis. Kedudukan guru sebagai tenaga profesional mempunyai visi terwujudnya penyelenggaraan pembelajaran sesuai dengan prinsip-prinsip profesionalitas untuk memenuhi hak yang sama bagi setiap warga Negara dalam memperoleh pendidikan bermutu. Tujuan penelitian adalah mengetahui implementasi supervisi akademik dalam peningkatan profesional guru taman kanak-kanak. Metode penelitian kualitatif. Adapun fokus implementasi supervisi akadamik dalam peningkatan profesional guru taman kanak-kanak meliputi bagaimana upaya peningkatan profesional guru taman kanak-kanak di TK PKK 1 Yosomulyo Metro Pusat Kota Metro. Hasil penelitian diperoleh data: (1) Perencanaan supervisi akademik dibuat dengan baik,(2) Pelaksanaan supervisi akademik dengan strategi supervisi silang dan supervisi tidak langsung, teknik supervisi akademik yang dilaksanakan oleh kepala sekolah menggunakan teknik supervisi kelompok dan teknik supervisi individu, (3) Evaluasi supervisi akademik dengan perbaikan dan motivasi kepada guru dari catatan dan temuan pada saat pelaksanaan supervisi akademik, (4) Hambatan supervisi akademik antara lain guru merasa terbebani saat diawasi, administrasi pembelajaran guru tidak lengkap, jadwal supervisi yang kadang bertentangan dengan acara kepala sekolah. Sedangkan solusi untuk mengatasi kendala tersebut antara lain memberikan pemahaman kepada guru tentang supervisi akademik, pemberian penghargaan, dan pengaturan jadwal yang efektif.
\end{abstract}

Kata kunci: Guru Profesional 1; Supervisi Akademik 2

\begin{abstract}
Professional teachers are an important factor in the world of education. Teachers as educational staff have functions and roles in strategic positions. The position of the teacher as a professional has a vision of realizing the implementation of learning in accordance with the principles of professionalism to fulfill the equal rights of every citizen in obtaining quality education. The purpose of the study was to determine the implementation of academic supervision in the professional improvement of kindergarten teachers. Qualitative research methods. The focus of the implementation of academic supervision in improving the professionalism of kindergarten teachers includes efforts to improve the professionalism of kindergarten teachers at PKK 1 Yosomulyo Kindergarten Metro City Center Metro. The results of the study obtained data: (1) Academic supervision planning was made well, (2) Implementation of academic supervision with cross-supervision strategies and indirect supervision, academic supervision techniques carried out by school principals using group supervision techniques and individual supervision techniques, (3) Evaluation of academic supervision with improvements and motivation to teachers from notes and findings during the implementation of academic supervision, (4) Obstacles to academic supervision include teachers feeling burdened when supervised, incomplete teacher learning administration, supervision schedules which sometimes conflict with the principal's program. Meanwhile, solutions to overcome these obstacles include providing teachers with an understanding of academic supervision, awarding, and setting an effective schedule.
\end{abstract}

Keyword: Professional Teachers1, Academic Supervision2 


\section{PENDAHULUAN}

Supervisi atau yang lebih dikenal dengan pengawasan pembelajaran memiliki konsep dasar yang saling berkaitan. dalam konsep dasar supervisi dijelaskan beberapa konsep-konsep supervisi itu sendiri. Supervisi memberikan pengaruh yang baik pada perkembangan pembelajaran di Indonesian sehingga para pendidik memiliki kemampuan yang kreatif, aktif dan inovatif dan dengan adanya supervisi maka kepala sekolah sebagai supervisor akan mengetahui bagaimana mengawasi dan mensupervisi pembelajaran yang baik.

Supervisi merupakan keharusan yang dilakukan oleh kepala sekolah dan diperlukan oleh guru, karena pendidik suatu titik pusat yang terdapat keterkaitan pada siswa dalam mendapatkan pengalaman belajar. Kualitas pendidik sangat mempengaruhi kegiatan serta hasil belajar murid. Maka, pendidik sangat membutuh kan seseorang yang memiliki informasi, pengertian serta pengetahuan yang melebihi pendidik. Hal ini sama pada petugasan pendidikan serta pengajaran. Supervisi yaitu suatu upaya untuk memberikan layanan untukpendidik jadi lebih perofessional untuk melaksanakan penugasan, melayani siswanya. Layanan perovisional kepala sekolah pada pendidik sangat esenssial untuk meningkatkan kualitas kegiatan pembelajaran. Pada saatl ini kepala sekolah perlu mepengaruhi kuaiilitas proses pembelajaran. Maka, esenssi supervisy academik itu sama sekali tida menilai tugas pendidik saat mengelola kan kegiatan belajar, melainkan membantu pendidik menumbuhkan kemampuan Profesionalnya. Pendidikyaitu orang yang berhak serta berwenang pada pendidikan untuk siswanya, baik dengan cara individual ataupun sengan caratim, baik disekolah ataupun diluar sekolah. Menurut Fatkhurrahman dan Suryana (2015: 6), bahwa supervisi akademik adalah bantuan professional kepada guru melalui siklus perencanaan yang sistimatis, pengamatan yang cermat dan hati-hati, serta umpan balik yang objektif dan segera.

Sebagaimana kutipan tersebut di atas bahwa supervisi akademik yaitu bagai pertolongan serta bimbingan pada pendidikpdajenis instruksional, belajar serta curiculum pada usahanya agarmeraih tujuan. Begitu pula yang disampaikan oleh Mukhtar dan Iskandar (2013: 47) bahwa supervisi akademik yaitu, supervisi yang menitik beratkan pengamatan pada masa akademik yang berlangsung berada dalam lingkup kegiatan pembelajaran yang dilakukan oleh guru untuk membantu siswa ketika sedang dalam proses belajar. Dengan kata lain, Supervisi yaitu salah suatu usaha meningkatan kualiitas pendidik yakni komponen SDM yang perlu dibina serta dikembangkan dengan komprehensip dan kontinyu. Potensi sumber daya guru perlu terus menerus dikembangkan untukpendidikbisamenjalankan fungsinya dengan preofessional.

Pengaruh beubahnya dengan kilat mendukung pendidik agar menerus dikembangkan untuk pendidik mampu nelaksanakan perannya dengan perofessional. adanya pengaruh peubahan yang sangat gesit menddukung pendidik dalam menyesuaikan dirinya secara pekembangan ilmu pengetahuan informasi serta teknology serta mobilitas masyarakat.

Upaya peningkatan profesional guru adalah melalui supervisi pengajaran. Pelaksanaan supervisi pengajaran perlu dilakukan secara sistematis oleh kepala sekolah dan pengawas sekolah yang bertujuan memberikan pembinaan kepada guru-guru agar dapat melaksanakan tugasnya secara efektif dan efisien. Dalam pelaksanaannya, kepala 
sekolah menggunakan observasi dan penilaian kemampuan guru untuk mencermati guru apakah professional dalam melaksanakan pembelajaran.

Profesional guru merupakan faktor penting dalam dunia pendidikan, pemerintah tidak pernah berhenti berupaya meningkatkan Profesional guru dan kesejahteraan guru. Pemerintah telah melakukan langkah-langkah strategis dalam rangka peningkatan kualifikasi, kompetensi, kesejahteraan, serta perlindungan hukum dan perlindungan profesi bagi mereka. langkah-langkah strategis ini perlu diambil karena apresiasi tinggi suatu bangsa terhadap guru sebagai penyandang profesi yang bermartabat merupakan pencerminan sekaligus sebagai salah satu ukuran martabat suatu bangsa.

Guru profesional memiliki kemampuan mengorganisasikan lingkungan belajar yang produktif. Kata profesi secara terminologi diartikan suatu pekerjaan yang mempersyaratkan pendidikan tinggi bagi pelakunya dengan titik tekan pada pekerjaan mental, bukan pekerjaan manual. Kemampuan mental yang dimaksudkan disini adalah ada persyaratan pengetahuan teoritis sebagai instrumen untuk melakukan perbuatan praktis.

Sebagai tenaga profesional, guru dituntut memvalidasi ilmunya, baik melalui belajar sendiri maupun melalui program pembinaan dan pengembangan yang dilembagakan oleh pemerintah atau masyarakat. Pembinaan merupakan upaya peningkatan profesional guru yang dapat dilakukan melalui kegiatan seminar, pelatihan, dan pendidikan. Pembinaan guru dilakukan dalam kerangka pembinaan profesi dan karir. Pembinaan profesi guru meliputi pembinaan kompetensi pedagogik, kompetensi profesional, dan kompetensi sosial. Pembinaan karier sebagai dimasuksudkan meliputi penugasan, kenaikan pangkat, dan promosi.

\section{METODE PENELITIAN}

Pendekatan yang penulis gunakan adalah pendekatan kualitatif, artinya penelitian yang mengambil data kualitatif. Metode penelitian kualitatif dapat juga diartikan sebagai metode penelitian yang berdasarkan pada filsafat postpositivisme, digunakan untuk meneliti pada kondisi objek yang alamiah, (sebagai lawannya adalah eksperimen) di mana peneliti adalah sebagai instrument kunci, pengambilan sampel sumber data dilakukan secara purposivedan snowball, teknik pengumpulan dengan trianggulasi (gabungan), analisis data bersifat induktif/kualitatif, dan hasil penelitian kualitatif lebih menekankan makna daripada generalisasi.

Pada penelitian kualitatif, peneliti memasuki situasi sosial tertentu yang dapat berupa lembaga pendidikan tertentu, melakukan observasi dan wawancara kepada orang-orang yang dipandang tahu tentang situasi sosial tersebut. Teori yang dikemukakan bersifat sementara dan akan berkermbang atau berubah setelah peneliti berada di lapangan. Margono menambahkan bahwa dalam penelitian kualitatif ini analisis yang digunakan lebih bersifat deskriptif analitik yang berarti interprestasi terhadap isi dibuat dan disusun secara sistematik/menyeluruh dan sistematis.

Alasan penggunaan metode kualitatif ini yaitu karena permasalahan belum jelas, holistik, kompleks, dinamis dan penuh makna sehingga tidak mungkin data pada situasi sosial tersebut dijaring dengan metode kuantitatif. Selain itu peneliti bermaksud memahami situasi ssosial secara mendalam, menemukan pola, hipotesis dan teori. Alasan penggunaan metode penelitian kualitatif ini juga dikarenakan : 1) lebih mudah mengadakan penyesuaian dengan kenyataan yang berdimensi ganda, 2) lebih mudah menyajikan secara langsung hakikat hubungan antara peneliti dan subjek penelitian, 3) 
memiliki kepekaan dan daya penyesuaian diri dengan banyak pengaruh yang timbul dari pola-pola nilai yang dihadapi.

Penelitian ini menggunakan pendekatan kualitatif. Pendekatan kualitatif sangat tepat untuk fokus dalam penelitian ini, karena beberapa alasan antara lain: (1) penelitian ini berupaya untuk menemukan permasalahan yang berkaitan dengan implementasi supervisi akademik kepala sekolah dalam peningkatan kompetensi profesional guru (2) penelitian ini bersifat induktif, dalam arti berusaha menemukan permasalahan berdasarkan data dan terbuka bagi penelitian lebih lanjut, dan (3) penelitian ini dilakukan dalam situasi yang wajar dan mengutamakan data yang bersifat kualitatif yang diperoleh dari informan.

\section{HASIL DAN PEMBAHASAN}

Perencanaan Supervisi Akademik Kepala Sekolah Dalam Peningkatan Profesional Guru Taman Kanak-Kanak

Kepala TK PKK 1 Yosomulyo Metro Pusat membuat perencanaan supervisi akademik diawali dengan menyusun tim supervisi. Tim supervisi terdiri dari kepala sekolah dan guru-guru senior yang memiliki kompetensi dan sudah bersertifikat yang diberi surat tugas oleh kepala sekolah untuk membantu melaksanakan supervisi akademik.

Kriteria dalam menyusun program supervisi akademik yang dilakukan kepala TK PKK 1 Yosomulyo mengacu pada pencapaian standar kompetensi lulusan, standar proses dan standar isi dengan tujuan meningkatkan kompetensi yang dimiliki guru. Kepala TK PKK 1 Yosomulyo membuat jadwal supervisi akademik pada semester ganjil dan semester genap yang waktu pelaksanaannya direncanakan terlebih dahulu oleh guru dan kepala sekolah agar guru mempersiapkan diri untuk supervisi akademik.

Jadwal yang dibuat oleh kepala merupakan jadwal tahapan supervisi akademik. Jadwal supervisi akademik meliputi: (1) penyusunan tim supervisi; (2) penyusunan jadwal supervisi; (3) pelaksanaan supervisi akademik; (4) evaluasi supervisi akademik; dan (5) tindak lanjut hasil supervisi akademik. Jadwal supervisi akademik dibuat oleh kepala sekolah diawal tahun ajaran baru. Pembagian tugas dan jadwal supervisi yang telah disepakati oleh tim supervisi selanjutnya akan disosialisasikan kepada guru melalui rapat. Pelaksanaan supervisi akademik dilaksanakan satu kali setiap semester. Artinya, guru hanya mendapatkan jadwal supervisi akademik satu kali setiap tahun ajaran. Supervisi akademik dilaksanakan pada pertengahan awal semester ganjil dan pertengahan awal semester genap yang untuk pelaksanaannya disepakati dengan guru supaya guru bisa mempersiapkan diri untuk supervisi akademik.

Perencanaan untuk program supervisi akademik kepala sekolah yang dibuat disesuaikan dengan kebutuhan peningkatan kompetensi pedagogik guru seperti pengelolaan kelas agar mencapai tujuan pembelajaran. sehingga dalam perencanaan dilakukan pembimbingan dalam peningkatan kompetensi pedagogik guru. Pembimbingan dilakukan melalui kegiatan pelatihan/workshop/IHT yang merupakan tindak lanjut dari hasil supervisi tahun sebelumnya dan dilakukan pengecekan administrasi pembelajaran. Sesuai dengan penjelasan Lantip Diat Prasojo dan Sudiyono (2011: 96) bahwa perencanaan program supervisi akademik adalah penyusunan dokumen perencanaan pemantauan serangkaian kegiatan membantu guru mengembangkan kemampuannya mengelola proses pembelajaran untuk mencapai tujuan pembelajaran. 
Tujuan supervisi akademik yang dilaksanakan di TK PKK 1 Yosomulyo yaitu: (1) Membantu guru dalam mengembangkan proses pembelajaran supaya tujuan pembelajaran tercapai; (2) Meningkatkan kemampuan guru dalam pembuatan administrasi pembelajaran; dan (3) Mengevaluasi kompetensi guru dalam rangka pembinaan guru. Dasar pertimbangan kepala sekolah dalam membantu guru adalah hasil pengamatan kepala sekolah dalam hal kompetensi pedagogik guru terkait dengan penguasaan kelas atau metode mengajar, serta hasil penilaian terhadap pembelajaran yang dilakukan guru mulai dari perencanaan pembelajaran hingga penilaian pembelajaran. Hal ini dilakukan untuk memperbaiki proses pembelajaran yang dilakukan oleh guru.

Pelaksanaan Supervisi Akademik Kepala Sekolah Dalam Peningkatan Profesional Guru Taman Kanak-Kanak

Pelaksanaan supervisi akademik kepala sekolah pada guru TK PKK 1 Yosomulyo yang sesuai dengan perencanaan yang sudah dibuat. Kepala sekolah tidak mungkin dapat melaksanakan supervisi secara sempurna, artinya kepala sekolah belum tentu menguasai seluruh mata pelajaran yang ada di sekolah. Strategi yang dilakukan kepala TK PKK 1 Yosomulyo adalah dengan supervisi langsung dan supervisi tidak langsung. Supervisi langsung adalah supervisi yang dilaksanakan langsung kepada guru baik dengan cara konsultasi, diskusi, kunjungan kelas dan rapat dewan guru. Sedangkan supervisi tidak langsung adalah dengan mendayagunakan orang atau sarana lain, bantuan guru senior (guru pembina) atau yang lainnya yang dipandang ahli dalam bidangnya, sehingga para guru diberi kesempatan untuk berkonsultasi pada mereka.

Prosedur pelaksanaan supervisi yang pertama adalah sosialisasi dengan para guru mengenai tujuan dan jadwal supervisi, kemudian kepala sekolah dan para guru yang ditunjuk membantu pelaksanaan supervisi akan melakukan kunjungan kelas sesuai dengan jadwal yang telah disepakati antara supervisor dengan guru yang bersangkutan. Kemudian hasil temuan saat kunjungan kelas akan didiskusikan antara guru dengan kepala sekolah dan selanjunya akan dilakukan evaluasi dan tindak lanjut.

Teknik kunjungan kelas yang dilakukan kepala sekolah dengan melakukan penilaian kepada guru dengan memberi skor pada setiap proses yang dilakukan oleh guru baik sebelum hingga proses penilaian pembelajaran. Sesuai dengan instrument yang sudah dibuat. Kunjungan kelas ini digunakan kepala sekolah untuk melihat bagaimana guru mengajar di kelas, metode yang digunakan serta media yang digunakan sehingga dapat menolong guru untuk mengatasi masalah-masalah pada saat pembelajaran. Teknik kunjungan kelas ini salah satu cara yang efektif untuk mengamati guru dalam proses pembelajarannya sehingga akan terlihat kelebihan dan kekurangan guru di kelas.

Teknik selanjutnya yang dilakukan kepala sekolah adalah dengan observasi kelas. Observasi kelas yang dilakukan kepala sekolah hanya melihat guru yang sedang di kelas bisa dari luar kelas ataupun di dalam kelas. Berbeda dari kunjungan kelas yang dilakukan pengamatan penuh selama pembelajaran berlangsung, untuk observasi kelas kepala sekolah hanya mengamati aspek-aspek yag dianggap perlu oleh kepala sekolah apabila data dianggap cukup kepala sekolah akan beralih mengobservasi kelas lainnya

Teknik supervisi lainnya yang dilakukan kepala sekolah adalah pembicaraan individu, dalam teknik ini kepala sekolah membimbing guru secara personal dengan cara berdialog langsung dengan guru baik secara formal maupun non formal. Secara formal pembicaraan individu berlangsung di ruang kepala sekolah untuk mendiskusikan 
permasalahan-permasalahan yang dihadapi guru terutama berkaitan dengan kompetensi profesional guru. Secara non formal pembicaraan individu berlangsung dimana saja bisa di halaman sekolah ataupun lapangan upacara untuk membicarakan berbagai hal terkait permasalahan guru. Melalui pembicaraan individu kepala sekolah dapat memberikan semangat dan motivasi kepada guru. Kepala sekolah juga dapat mengecek keluhan-keluhan peserta didik dan walimurid yang disampaikan guru.

Selanjutnya teknik yang digunakan adalah rapat dewan guru. Rapat dewan guru dilakukan untuk memberikan berbagai informasi terkait dengan sekolah seperti informasi kurikulum baru dan pengarahan-pengarahan lainnya. Rapat dewan guru ini dilakukan di awal dan akhir semester serta setiap bulannya. Kegiatan rapat dewan guru ini merupakan bentuk pembinaan yang dilakukan kepala sekolah.

Supervisi akademik yang diberikan kepala sekolah diantaranya berbagai masalah terkait kompetensi profesional guru diantaranya (1) mengembangkan kurikulum (2) kegiatan pembelajaran yang mendidik (3) mengembangkan potensi peserta didik (4) termasuk masalah-masalah yang dianggap kepala sekolah perlu pendapat guru. Untuk mengetahui guru menguasai kompetensi pedagogik dalam pelaksanaan supervisi akademik kepala TK PKK 1 Yosomulyo maka dilakukan pembahasan tentang tiga aspek kompetensi profesional guru yaitu mengembangkan kurikulum, kegiatan pembelajaran yang mendidik dan mengembangkan potensi peserta didik.

Profesional guru pada aspek mengembangkan kurilkulum, disini guru belum dapat menyusun silabus yang sesuai dengan kurikulum, guru belum merancang rencana pembelajaran yang sesuai dengan silabus dan guru belum mengikuti urutan materi pembelajaran dengan memperhatikan tujuan pembelajaran. Hal ini tidak sejalan dengan indikator ketercapaian aspek mengembangkan kurikulum pada kompetensi pedagogik sesuai dengan pedoman penilaian kinerja guru, yaitu guru dapat menyusun silabus yang sesuai dengan kurikulum, guru merancang rencana pembelajaran yang sesuai dengan silabus untuk membahas materi ajar tertentu agar peserta didik dapat mencapai kompetensi dasar yang ditetapkan, guru mengikuti urutan materi pembelajaran dengan memperhatikan tujuan pembelajaran, guru memilih materi pembelajaran yang: (1) sesuai dengan tujuan pembelajaran, (2) tepat dan mutakhir, (3) sesuai dengan usia dan tingkat kemampuan belajar peserta didik, (4) dapat dilaksanakan di kelas dan (5) sesuai dengan konteks kehidupan sehari-hari peserta didik.

Profesional guru pada aspek kegiatan pembelajaran yang mendidik, disini guru TK PKK 1 Yosomulyo sudah mampu melaksanakan kegiatan pembelajaran yang sesuai dengan kebutuhan peserta didik, guru melaksanakan aktivitas pembelajaran yang bertujuan untuk membantu proses belajar peserta didik, guru melakukan pembelajaran yang berpusat pada peserta didik, guru tidak mendominasi pembelajaran dan sebagian guru memanfaatkan teknologi informasi komunikasi (TIK) untuk kepentingan pembelajaran. Hal ini sejalan dengan indikator ketercapaian aspek kegiatan pembelajaran yang mendidik pada kompetensi pedagogik sesuai dengan pedoman penilaian kinerja guru, yaitu guru melaksanakan aktivitas pembelajaran yang bertujuan untuk membantu proses belajar peserta didik, bukan untuk menguji sehingga membuat peserta didik merasa tertekan, guru menyikapi kesalahan yang dilakukan peserta didik sebagai tahapan proses pembelajaran, bukan semata-mata kesalahan yang harus dikoreksi. Misalnya: dengan mengetahui terlebih dahulu peserta didik lain yang setuju/tidak setuju dengan jawaban tersebut, sebelum memberikan penjelasan tentang jawaban yamg benar, guru melaksanakan kegiatan pembelajaran sesuai isi kurikulum dan mengkaitkannya dengan konteks kehidupan sehari-hari peserta didik, guru 
melakukan aktivitas pembelajaran secara bervariasi dengan waktu yang cukup untuk kegiatan pembelajaran yang sesuai dengan usia dan tingkat kemampuan belajar dan mempertahankan perhatian peserta didik, guru mengelola kelas dengan efektif tanpa mendominasi atau sibuk dengan kegiatannya sendiri agar semua waktu peserta dapat termanfaatkan secara produktif, guru mampu memanfaatkan audio-visual (termasuk TIK) untuk meningkatkan motivasi belajar peserta didik dalam mencapai tujuan pembelajaran. Menyesuaikan aktivitas pembelajaran yang dirancang dengan kondisi kelas, guru memberikan banyak kesempatan kepada peserta didik untuk bertanya, mempraktekkan dan berinteraksi dengan peserta didik lain.

Evaluasi Supervisi Akademik Kepala Sekolah dalam Peningkatan Profesional Guru Taman Kanak-Kanak

Evaluasi supervisi akademik yang dilakukan kepala TK PKK 1 Yosomulyo berupaya untuk meningkatkan kompetensi pedagogik guru. Kepala TK PKK 1 Yosomulyo melakukan evaluasi dengan memberi perbaikan dan motivasi kepada guru dari hasil catatan dan temuan-temuan pada saat pelaksanaan supervisi akademik. Setelah melakukan evaluasi kepala sekolah selanjutnya memberikan tindak lanjut kepada guru sebagai pembinaan agar terjadi peningkatan kompetensi pedagogik guru. Tindak lanjut yang dilakukan terhadap hasil supervisi adalah dengan mengadakan pelatihan/workshop/IHT, mengikutsertakan kegiatan PKG dengan guru-guru di sekolah dan guru-guru sekolah lain, menyarankan guru untuk berdiskusi dengan teman sejawat.

Hasil supervisi akademik di TK PKK 1 Yosomulyo dilakukan kepala sekolah dengan menganalisa secara bersama dengan guru hasil supervisi akademik yang telah dilaksanakan. Selanjutnya, hasil supervisi akademik terkait masalah yang sifatnya umum, evaluasi akan dilakukan melalui rapat antara kepala sekolah dengan para guru. Selanjutnya, pelaksanaan evaluasi hasil supervisi akademik di TK PKK 1 Yosomulyo dilaksanakan kepala sekolah dengan menyampaikan temuan-temuan kepala sekolah sewaktu melakukan observasi kelas dan kunjungan kelas kepada guru yang bersangkutan. Hasil temuan tersebut disampaikan melalui pembicaraan individu antara kepala sekolah dengan guru. Selain itu, temuan yang sifatnya umum akan disampaikan melalui rapat antara kepala sekolah dengan guru.

Pelaksanaan evaluasi hasil supervisi akademik yang dilaksanakan di TK PKK 1 Yosomulyo apabila dilihat dengan memperhatikan teori tersebut, maka kepala sekolah sudah mendiskusikan hasil supervisi akademik dengan guru melalui pertemuan individu dan rapat dewan guru, kepala sekolah sudah memberikan penghargaan bagi guru yang telah memenuhi standar dalam pemenuhan administrasi pembelajaran dengan memberikan reward.

Kelebihan dan kekurangan pada Implementasi Supervisi Akademik dalam peningkatan Profesional Guru

Hambatan-hambatan sebagai kekurangan yang ditemui pada implementasi supervisi akademik dalam peningkatan kompetensi profesional kepala TK PKK 1 Yosomulyo diantaranya:

1. Guru merasa terbebani ketika disupervisi

Masalah ini merupakan masalah yang umum terjadi ketika guru disupervisi oleh kepala sekolah. Salah satu penyebab guru merasa terbebani karena masih melekatnya anggapan guru bahwa supervisi semata-mata hanya kegiatan untuk mencari-cari kesalahan guru. 
2. Administrasi pembelajaran guru belum lengkap

Masalah ini terjadi karena guru tidak lengkap mempersiapkan administrasi pembelajarannya. Administrasi yang terkadang belum lengkap disiapkan seperti program tahunan, program semester, silabus, RPP, kisi-kisi soal dan kartu soal.

3. Jadwal supervisi yang kadang berbenturan dengan acara kepala sekolah Masalah ini terjadi karena kepala sekolah terlalu sibuk dengan berbagai urusan dan tugas-tugas lainnya sehingga kegiatan supervisi akademik tidak dapat ditangani sendiri, khususnya supervisi yang lebih menekankan pada kompetensi pedagogik dalam perbaikan pembelajaran.

4. Unsur subjektifitas guru supervisor dirasa masih tinggi

Masalah ini terjadi karena supervisi akademik tidak dilakukan sendiri oleh kepala sekolah, tim supervisi yang dibentuk memiliki kepribadian yang berbeda-beda dan prinsip supervisi yang berbeda-beda pula.

5. Masih ada guru yang enggan disupervisi

Masalah ini terjadi karena tidak siapnya guru ketika dipantau atau dimonitoring kegiatan pembelajarannya di kelas. Guru merasa tidak nyaman dan canggung jika disupervisi.

Upaya yang dilakukan kepala TK PKK 1 Yosomulyo dalam mengatasi kekurangan dari kegiatan supervisi akademik diantaranya dengan:

1. Memberi pemaham guru tentang supervisi akademik

Guru diberikan pemahaman tentang supervisi akademik melalui motivasi kepala sekolah agar menjadikan supervisi akademik sebagai kebutuhan guru.

2. Pemberian reward (penghargaan)

Hal ini dilakukan kepala sekolah untuk memotivasi guru dalam melengkapi administrasi pembelajaranya sehingga supervisi akademik dapat terlaksana dengan baik guna untuk meningkatkan kompetensi profesional guru.

3. Pengaturan jadwal yang efektif

Kepala sekolah harus menyisakan waktu yang dimilikinya untuk kegiatan supervisi akademik.

4. Pengarahan guru senior yang bertugas sebagai supervisor

Guru senior yang ditugaskan menjadi supervisor harus memiliki kriteria khusus dalam pelaksanaan supervisi akademik.

\section{KESIMPULAN DAN SARAN}

Program supervisi akademik kepala sekolah yang dibuat disesuaikan dengan kebutuhan peningkatan kompetensi pedagogik guru, sehingga dalam perencanaan dilakukan pembimbingan dalam peningkatan kompetensi pedagogik guru melalui pengecekan administrasi pembelajaran dan kegiatan pelatihan/workshop/IHT yang merupakan tindak lanjut dari hasil supervisi tahun sebelumnya. Namun kepala sekolah belum mencantumkan secara jelas mengenai teknik dan strategi akan diterapkan saat melaksanakan supervisi akademik pada dokumen perencanaan supervisi

Kekurangan dari supervisi akademik yang ditemui kepala TK PKK 1 Yosomulyo diantaranya guru merasa terbebani ketika disupervisi, administrasi pembelajaran guru belum lengkap, jadwal supervisi yang kadang berbenturan dengan acara kepala sekolah, Unsur subjektifitas guru supervisor dirasa masih tinggi dan Masih ada guru yang enggan disupervisi. Sedangkan solusi dalam mengatasi hambatanhambatan tersebut diantaranya dengan memberi pemaham guru tentang supervisi 
akademik, pemberian reward (penghargaan), pengaturan jadwal yang efektif dan pengarahan guru senior yang bertugas sebagai supervisor.

\section{DAFTAR PUSTAKA}

Aan Komariah, Djam'an Satori. (2012). Metode Penelitian Kualitatif. Bandung: Alfabeta

Abdul Aziz, Hamka. (2012). Karakter Guru Profesional. Jakarta: Al Mawardi

Departemen Pendidikan Nasional. (2007). Pendidikan dan Pelatihan: Supervisi Akademik dalam Peningkatan Profesionalisme Guru. Jakarta: Depdiknas. . (2009). Metode, Teknik Supervisi Akademik dan Pengembangan Instrumen. Jakarta: Depdiknas.

Hariyati, Sri. (2021). Peningkatan Kemampuan Profesional Guru Melalui Supervisi Akademik Teknik Individual Conference (Ic) oleh Kepala Sekolah Di Tk Handayani Desa Ketro Kecamatan Tulakan Kabupaten Pacitan. Jurnal Wahana Kreatifitas Pendidik. Vol IV No 2 Tahun 2021, Hal 77-85.

Juhri AM. (2018). Supervisi Pendidikan. Metro: Laduny Alifatama, Anggota IKAPI.

Karsiyem. (2015). Pelaksanaan Supervisi Akademik dalam Peningkatan Kinerja Guru Sekolah Dasar Gugus III Sentolo Kulon Progo. Yogyakarta: Jurnal Akuntabilitas Manajemen Pendidikan Vol.3.

Khumairoh, Nur Maulidiyatul., Supriyanto. (2021). Peran Supervisi Akademik dalam Meningkatkan Kompetensi Profesional Guru. Jurnal Inspirasi Manajemen Pendidikan. Vol 9 No 3 Tahun 2021, Hal 794-807.

Lantip Diat Prasojo, dkk. (2011). Supervisi Pendidikan. Yogyakarta: Gava Media.

Sagala, Syaiful. (2009). Kemampuan Profesional Guru dan Tenaga Kependidikan. Bandung: Alfabeta.

Sahertian, Piet A. (2008). Supervisi Pendidikan. Jakarta: Rineka Cipta.

Sari, Yosi Melda., Ahmad Huzairin. (2021). Manajemen Supervisi Dalam Lembaga PAUD Di TK Negeri Pembina Nasal. Jurnal PAUDIA. Vol 10 No 1 Hal 186-196.

Tim Pengembang Bahan Pembelajaran Lembaga Pengembangan dan Pemberdayaan Kepala Sekolah (LPPKS). (2011). Supervisi Akademik Modul. Karanganyar: LPPKS. 